\title{
The role of TNF in tumour growth and metastasis
}

\author{
D.N. Männel (1), J. Rüschoff ${ }^{(1)}$ and P. Orosz ${ }^{(2)}$ \\ (I) Tumor immunology, Dept. of Pathology, University of Regensburg, Regensburg (Germany) and \\ ${ }^{(2)}$ Dept. of Immunology, German Cancer Research Center, Heidelberg (Germany)
}

The capacity of TNF to induce necrosis of solid tumours in vivo and its cytostatic and cytotoxic activities toward tumour cclls in vitro promoted intensive research on this molecule and is very well established (Carswell et al., 1975; Haranaka et al., 1984; Old, 1985; Palladino et al., 1987). Application of high-dose recombinant TNF in a combination treatment protocol using isolation limp perfusion clearly demonstrates the antitumoral activity of TNF by selectively destroying the tumour vasculature (Lienard et al., 1992). However, TNF, in addition to the antitumour effects, has a broad spectrum of biological effects that can complicate its use as an antitumor agent. The induction of IL1 (Dinarello et $a l ., 1986)$ and IFN- $\beta$ (Kohase et al., 1986), the enhanced expression of HLA genes in tumour cells (Pfizenmaier et al., 1987), or the supportive effect on NK (Männel et al., 1989) and LAK (McIntosh et al., 1989) activity might contribute to the beneficial antitumoral activity of TNF.

The role of endogenous TNF in the pathophysiology of cancer and metastasis is controversially discussed. Only limited information is available demonstrating enhanced levels in serum or tumour specimens of cancer patients (Naylor et al., 1990; Balkwill et al., 1987) and in tumour-bearing animals (Rakhmilevich and North, 1991; Männel et al., 1990). Such endogenous TNF might also contribute to tumour progression. TNF is able to activate enzyme cascades that may enhance the tumour spread, e.g. proteases (Opdenakker and Van Damme, 1992; Dayer et al., 1985), to stimulate angiogenesis in vivo (Frater Schroder et al., 1987) and to increase the adherence of tumour cells to endothelium in vitro (Rice et al., 1988; Dejana et al., 1988; Bereta et al., 1991). It has also been shown that TNF promotes the invasive growth of tumour cells in the peritoneum and their establishment as tumour nodules below the mesothelial surface (Malik et al., 1989, 1990).

\section{TNF and endothelial adhesion}

Experiments concerning the influence of exogenous TNF on metastasis had rather controversial results. In a murine fibrosarcoma model (Tomazic et al., 1988), a lung cancer model (Schultz and Altom, 1990) and in melanoma models (Sylvester et al., 1990; Lollini et al., 1990), inhibition of formation of metastases by rhTNF has been reported when rhTNF was given within 3 days of tumour cell inoculation. On the other hand, administration of rhTNF led to an increase in pulmonary metastasis when given $1 \mathrm{~h}$ prior to i.v. inoculation of a human melanoma cell line into nude mice (Giavazzi et al., 1990) or promoted the implantation of human ovarian cancer xenografts in the peritoneal cavity of nude mice (Malik et al., 1989).

In an experimental metastasis model, mice received syngeneic fibrosarcoma cells (CFSI) i.v. The injection of either rmTNF or rhTNF $5 \mathrm{~h}$ prior to tumour cell inoculation led to a dose-dependent augmentation in the number of tumour colonies counted on the surface of the lungs after 12 days (fig. 1) (Orosz et al., 1993). The stronger metastasispromoting activity of rmTNF compared to rhTNF demonstrated the described species preference of TNF (Kramer et al., 1988; Brouckaert et al., 1992) and might be explained by species-specific activities mediated via the mouse p75 TNF receptor. Application of bacterial endotoxin (LPS) also augments metastasis, possibly by inducing endogenous TNF. Therefore, LPS contamination of the rmTNF and rhTNF preparation, respectively, was excluded by heating the TNF to $100^{\circ} \mathrm{C}$ for 15 min. This treatment destroyed the metastasis-enhancing capacity completely. A significant increase in the colonies on the lungs compared to control mice was observed only when rmTNF was given $5 \mathrm{~h}$ prior to or $1 \mathrm{~h}$ after tumour cells. Application of TNF $24 \mathrm{~h}$ before or $24 \mathrm{~h}$ and up to 4 days after tumour cell injection had no significant effect on pulmonary metastasis. Also, in vitro pretreatment of tumour cells with TNF had no influcnce on metastasis, in contrast to results described in a melanoma model (Lollini et al., 1990). These results suggest that the observed metastasispromoting effect might reside in an influence of TNF on the interaction of circulating tumour cells with the endothelium supporting the arrest, diapedesis and extravasation of the tumour cells. 


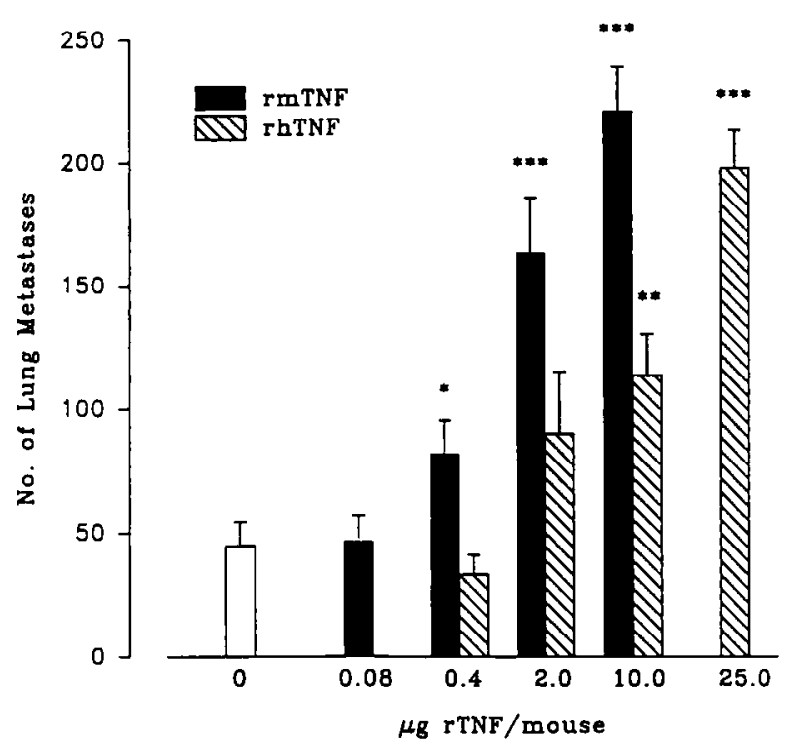

Fig. 1. Increase in experimental lung metastasis by different concentrations of rmTNF and rhTNF.

Mice were given i.p. injections of different concentrations of rmTNF or rhTNF $5 \mathrm{~h}$ prior to i.v. CFSI tumor cell injection $\left(3 \times 10^{5}\right)$. Control mice received the same volume of PBS. Results are expressed as mean \pm SEM. $\mathrm{n}=12$ for control group; $\mathrm{n}=6$ for TNF treated groups. ${ }^{* * *} \mathrm{p}<0.001 ;{ }^{* *} \mathrm{p}<0.005$; $^{*} \mathrm{p}<0.05$.

Since tumour-bearing mice showed an enhanced capacity for TNF production, the influence of endogenous TNF on the formation of lung metastases was investigated by injecting i.v. neutralizing antimouse TNF monoclonal antibodies (V1q) (Echtenacher et al., 1990) $5 \mathrm{~h}$ before tumour cell inoculation. The neutralization of endogenous TNF induced a significant decrease in metastasis (table I), demonstrating a supportive effect of endogenously produced TNF for metastasis. Whether this TNF effect is due to enhanced expression of adhesion molecules on endothelial cells and/or tumour cells by a direct action of TNF on these cells or whether it is mediated via additional cells, e.g. granulocytes or platelets, is currently being investigated. A recent report demonstrating abolishment of TNF-induced enhanced metastasis in a similar model by blocking adhesion strongly supports the hypothesis of adhesion promotion by TNF. It has been reported that synthetic peptides containing recognition sequences of cell adhesion molecules (i.e., Arg-Gly-Asp (RGD) in fibronectin and Tyr-Ile-Gly-Ser-Arg (YIGSR) in laminin) inhibit the development of tumour metastasis (Iwamoto et al., 1987; Saiki et al., 1989). A modified TNF molecule which carried the laminin-derived peptide YIGSR on the $\mathrm{N}$-terminus did not enhance experimental metastasis, in contrast to unmodified TNF (Miyata et al., 1992).

Tumour cell metastasis could be regulated in a similar way as lymphocyte migration from blood into tissue. Activation of integrins that mediate adhesion of $T$ cells to the endothelium can be achieved by proteoglycan-immobilized cytokines, e.g. MIP-1 $\beta$ (Tanaka et al., 1993). A cellular proteoglycan that could serve the function of anchoring the activating cytokines is CD44, which has also been shown to be involved in regulation of metastasis (Arch et al., 1992). It could be speculated that enhancement of expression of such activating cytokines by TNF might be one possible mechanism by which TNF increases the adherence of tumour cells to the endothelium (Rice et al., 1988; Dejana et al., 1988; Bereta et al., 1991).

Preliminary evidence from our experiments using thrombocytopenic mice also indicates an involvement of platelets in the extravasation steps of metastasis. Ample data showing a correlation of metastasis with platelet aggregation can be found in the literature (Mogi et al., 1991 ; Tzanakakis et al., 1991 ; Nierodzik et al., 1991 ; Sugimoto et al., 1991 ; Okoshi et al., 1991 ; Ordinas et ul., 1990). TNF leads to platelet activation via stimulation of granulocytes (Renesto and Chignard, 1991). The exact mechanisms, cells, and molecules involved in such a metastasis-provoking situation have yet to be analysed.

Table I. Reduction of experimental metastasis by neutralization of endogenous TNF.

\begin{tabular}{lcccc} 
Pretreatment & $\mathrm{n}$ & No. of lung metastases & $\mathrm{p}$ \\
\hline PBS control & 8 & $58.5 \pm 7.9$ & Range & \\
Rat anti-mTNF (VIq) & 6 & $9.6 \pm 5.6$ & $22-82$ & $1-31$ \\
Rat IgG & 6 & $66.9 \pm 18.0$ & $23-114$ & \\
\hline
\end{tabular}

Mice were treated i.p. with the indicated substances $5 \mathrm{~h}$ before i.v. CFSl tumour cell injection $\left(3 \times 10^{5}\right)$. Animals were killed on day 11 , lungs were removed and number of surface colonies was counted. 
Table II. Enhancement of tumour cell proliferation rate in vivo by rmTNF.

\begin{tabular}{lccc} 
AgNOR parameter & \multicolumn{2}{c}{ Pretreatment } & \\
PBS control & $\begin{array}{c}\text { rmTNF } \\
\text { (mean } \pm \text { SEM) }\end{array}$ & (mean \pm SEM) & p \\
\hline No. of AgNOR/cell & $1.2 \pm 1.2$ & $8.4 \pm 0.7$ & $<0.001$ \\
AgNOR area $\left(\mu \mathrm{m}^{2}\right) /$ AgNOR & $0.02 \pm 0.02$ & $0.13 \pm 0.01$ & $<0.001$ \\
AgNOR content/cell & $9.4 \pm 9.4$ & $65.8 \pm 5.6$ & $<0.001$ \\
\hline
\end{tabular}

Mice received $10 \mu \mathrm{g} \mathrm{rmTNF}$ or $100 \mu \mathrm{l}$ PBS $5 \mathrm{~h}$ prior to i.v. tumour cell inoculation. Lungs were removed on day 5 , fixed in formalin and AgNOR parameters were determined. $n=6$ per group.

\section{TNF and cell activation}

Histological analysis of lung sections from rmTNF-pretreated mice 5 days after tumour cell inoculation showed more and larger pulmonary metastases in the septae of the lung parenchyma (fig. 2). Number and size of silver-stained proteins associated with nuclear organizer regions (AgNOR) per cell were determined on paraffin sections by digital image analysis as a parameter for in vivo proliferation (Ruschoff et al., 1990). Lung sections from rmTNF-pretreated mice showed a significantly enhanced number of AgNOR dots, AgNOR area and AgNOR content per cell, indicating an augmented proliferation rate compared to the control group (fig. 2, table II). In vitro treatment with TNF, however, did not influence the proliferation rate of the fibrosarcoma cells, indicating that the augmented metabolic and proliferative activity in vivo might be host-dependent. Preliminary data with tumour cells growing as spheroids in three-dimensional culture indicated opposing effects of TNF. At lower TNF concentrations, the size of the tumour spheroids was larger compared to TNF-free cultures, whereas at higher TNF concentrations, the tumour spheroids remained very small (unpublished results). Since TNF has been shown to exert growth stimulatory activaties on some cell types (Sugarman et al., 1985) growth-promoting and growth-inhibitory activities could be two overlapping functions of TNF. The mechanisms of the apparently opposing effects remain to be analysed.
A similar bimodal effect of TNF was also observed in angiogenesis. Whereas angiogenesis was inhibited at high concentrations of TNF, low concentrations induced it (Fajardo et al., 1992). Thus, in a situation of low tissue concentration, $\mathrm{TNF}$ might support the growth of microvessels in neoplasms and therefore eventually promote tumour growth. Recent data seem to support this hypothesis. Fibrosarcoma cells overexpressing tissue factor and growing as solid tumours showed better in vivo growth than those expressing low amounts (P. Nawroth, personal communication). Since TNF is an inducer of tissue factor expression on some cell types (Conway et al., 1989; Wiggins et al., 1990; Tanaka, 1989) such indirect effector mechanisms might also be involved in the complex regulation of tumour growth.

A positive correlation of stimulated immune status with poor prognosis and enhanced metastasis has been found (Reibnegger et al., 1987, 1991). The determination of enhanced levels of neopterin, a macrophage-derived product, and IL6 in tumour patients served as parameters for the stimulated immune system. Increased neopterin and IL6 production are possible consequences of enhanced TNF production. In support of this observation is a recent study that directly documents increased blood TNF levels in metastatic cancer patients over those without metastases (Ardizzoia et al., 1992). This correlation of exaggerated TNF secretion with neoplastic metastatic disease supports the pathological role of TNF in metastasis.

Fig. 2. Histological sections of lung tissue from untreated mice (a,c) or TNF-treated mice (b,d) exhibiting small metastatic tumour nodules within alveolar septae (arrows).

Haematoxylin/eosin stain; a) original $\times 400$, b) original $\times 200$. Nodule of metastatic tumour cells showing multiple silver stained NOR dots (AgNOR) within nuclei (arrows). c,d) AgNOR stain, original $\times 2,500$. 


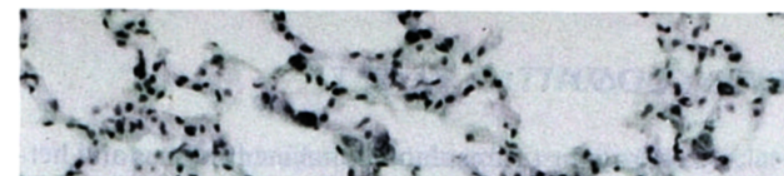
$3,1+2 w^{16}$

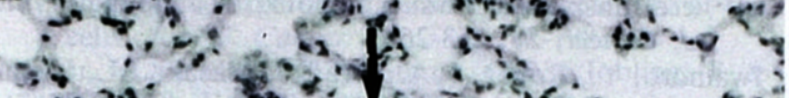
D. 200 हैं



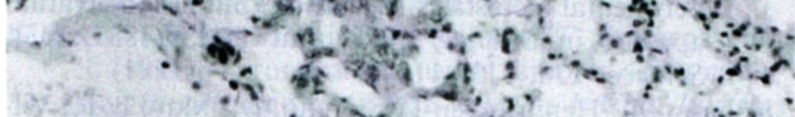

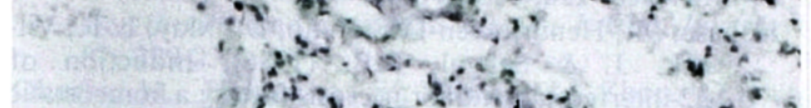

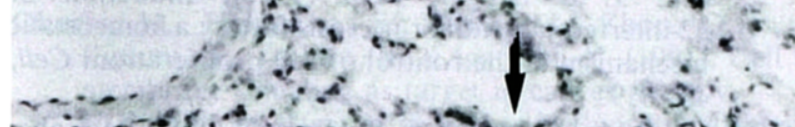

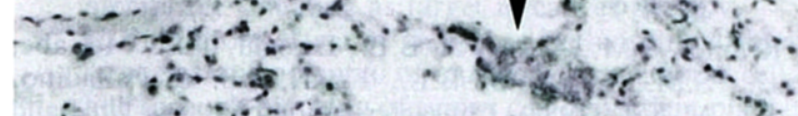

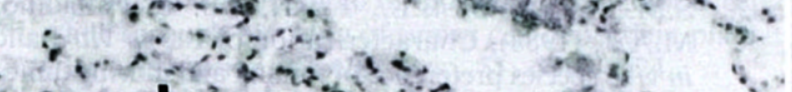

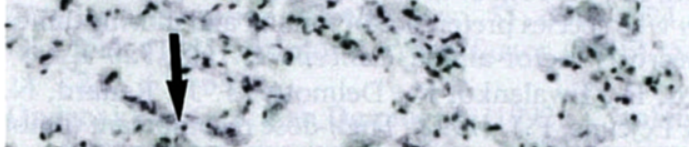

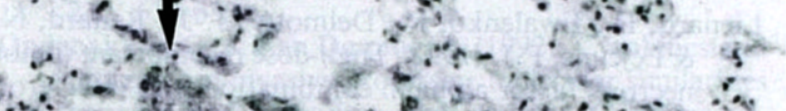

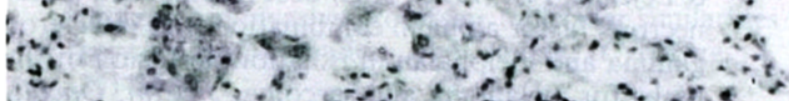

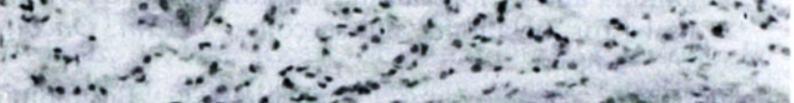
$x_{3}-040$. in $v^{2}$ $10: 4)^{2}$ के

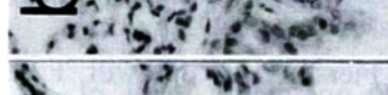

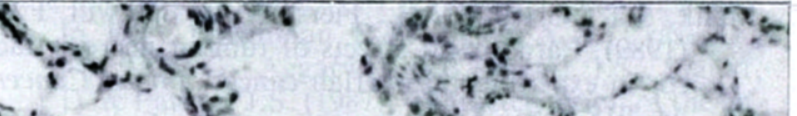
is:-

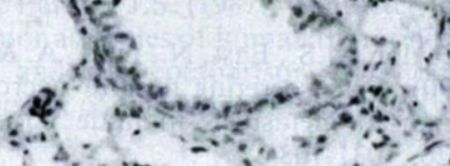

Eano

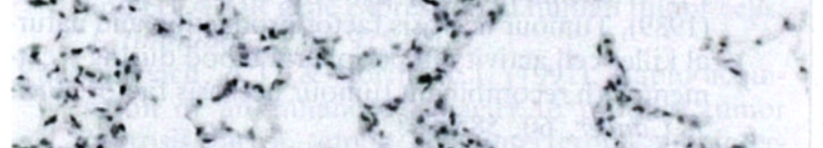

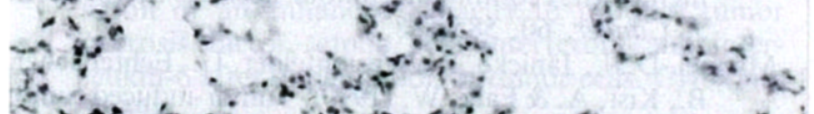

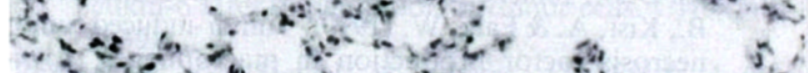
in, $\quad \because 4$

-

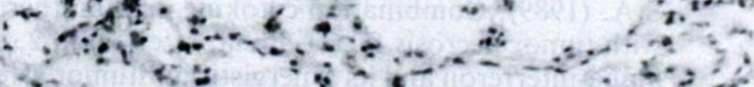

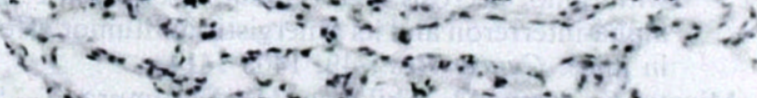

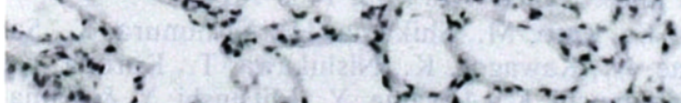
(4)

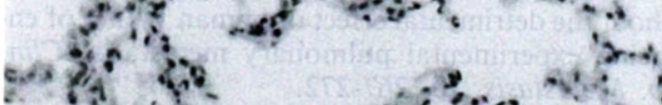

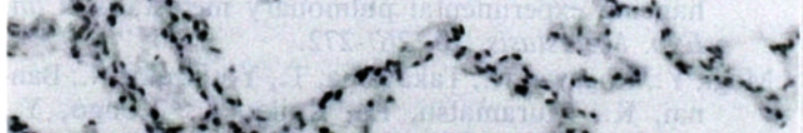
क

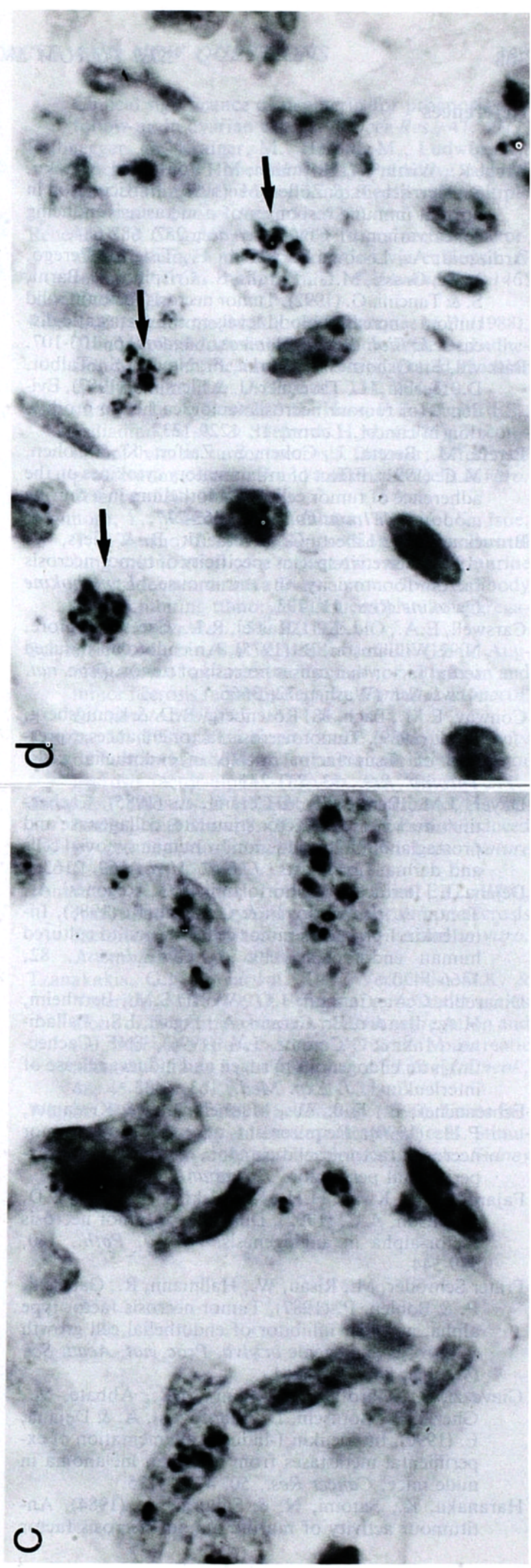




\section{References}

Arch, R., Wirth, K., Hofmann, M., Ponta, H., Matzku, S., Herrlich, P. \& Zöller, M. (1992), Participation in normal immune responses of a metastasis-inducing splice variant of CD44. Science, 257, 682-684.

Ardizzoia, A., Lissoni, P., Brivio, F., Tisi, E., Perego, M.S., Grassi, M.G., Pittalis, S., Crispino, S., Barni, S. \& Tancini, G. (1992), Tumor necrosis factor in solid tumors: increased blood levels in the metastatic disease. J. Biol. Regul. Homeost. Agents, 6, 103-107.

Balkwill, F., Osborne, R., Burke, F., Naylor, S., Talbot, D., Durbin, H., Tavernier, J. \& Fiers, W. (1987), Evidence for tumour necrosis factor/cachectin production in cancer. Lancet, II, 1229-1232.

Bereta, M., Bereta, J., Cohen, S., Zaifert, K. \& Cohen, M.C. (1991), Effect of inflammatory cytokines on the adherencc of tumor cells to endothclium in a murine model. Cell Immunol., 136, 263-277.

Brouckaert, P., Libert, C., Everaerdt, B. \& Fiers, W. (1992), Selective species specificity of tumor necrosis factor for toxicity in the mouse. Lymphokine Cyrokine Res., 11, 193.

Carswell, E.A., Old, L.J., Kassel, R.L., Green, S., Fiore, N. \& Williamson, B. (1975), An endotoxin-induced serum factor that causes necrosis of tumor. Proc. nat. Acad. Sci. (Wash.), 72, 3666.

Conway, E.M., Bach, R., Rosenberg, R.D. \& Konigsberg, W.H. (1989), Tumor necrosis factor enhances expression of tissue factor mRNA in endothelial cells. Thromb. Kes., 53, 231-241.

Dayer, J.M., Beutler, B. \& Cerami, A. (1985), Cachectin/tumor necrosis factor stimulates collagenase and prostaglandin E2 production by human synovial cells and dermal fibroblasts. J. Exp. Med., 162, 2163.

Dejana, E., Bertocchi, F., Bortolami, M.C., Regonesi, A., Tonta, A., Breviario, F. \& Giavazzi, R. (1988), Interleukin 1 promotes tumor cell adhesion to cultured human endothelial cells. J. Clin. Invest., 82, 1466-1470.

Dinarello, C.A., Cannon, J.G., Wolff, S.M., Bernheim, H.A., Beutler, B., Cerami, A., Figari, I.S., Palladino, M.A. \& O'Connor, J.V. (1996), TNF (Cachectin) is an endogenous pyrogen and induces release of interleukin-1. J. Exp. Med., 163, 1433.

Echtenacher, B., Falk, W., Männel, D.N. \& Krammer, P.H. (1990), Requirement of endogenous tumor necrosis factor/cachectin for recovery from experimental peritonitis. J. Immunol., 145, 3762.

Fajardo, L.F., Kwan, H.H., Kowalski, J., Prionas, S.D. \& Allison, A.C. (1992), Dual role of tumor necrosis factor-alpha in angiogenesis. Am. J. Palh., 140, 539-544.

Frater Schroder, M., Risau, W., Hallmann, R., Gautschi, P. \& Bohlen, P. (1987), Tumor necrosis factor type alpha, a potent inhibitor of endothclial cell growth in vitro, is angiogenic in vivo. Proc. nat. Acad. Sci. (Wash.), 84, 5277-5281.

Giavazzi, R., Garofalo, A., Bani, M.R., Abbate, M., Ghezzi, P., Boraschi, D., Mantovani, A. \& Dejana, E. (1990), Interleukin 1-induced augmentation of experimental metastases from a human melanoma in nude mice. Cancer Res., 50, 4771-4775.

Haranaka, K., Satomi, N. \& Sakurai, A. (1984), Antitumour activity of murine tumour necrosis factor
(TNF) against transplanted murine tumours and heterotransplanted human tumours in nude mice. $\mathrm{lnt}$. J. Cancer, 34, 263-266.

Iwamoto, Y., Robey, F.A., Graf, J., Sasaki, M., Kleinman, H.K., Yamada, Y. \& Martin, G.R. (1987), YIGSR, a synthetic laminin pentapeptide, inhibits experimental metastasis formation [published erratum appears in Science, 1988, Jan 15;239(4837):245]. Science, 238, 1132-1134.

Kohase, M., Hendricksen-DeStefano, D., May, L.T., Vilcek, J. \& Schgal, P.B. (1986), Induction of $\beta 2$-interferon by tumor necrosis factor : a homeostatic mechanism in the control of cell proliferation. Cell, 45,659 .

Kramer, S.M., Aggarwal, B.B., Eessalu, T.E., McCabe, S.M., Ferraiolo, B.L., Figari, I.S. \& Palladino, M.A.J. (1988), Characterization of the in vitro and in vivo species preference of human and murine tumor necrosis factor-alpha. Cancer Res., 48, 920-925.

Lienard, D., Ewalenko, P., Delmotte, J.-J., Renard, N. \& Lejeune, F.J. (1992), High-dose recombinant tumor necrosis factor alpha in combination with interferon gamma and melphalan in isolation perfusion of the limbs for melanoma and sarcoma. J. Clin. Oncol., $10,52-60$.

Lollini, P.L., De Giovanni, C., Nicoletti, G., Bontadini, A., Tazzari, P.L., Landuzzi, L., Scotlandi, K. \& Nanni, P. (1990), Enhancement of experimental metastatic ability by tumor necrosis factor-alpha alone or in combination with interferon-gamma. Clin. Exp. Metastasis, 8, 215-224.

Malik, S.T., Griffin, D.B., Fiers, W. \& Balkwill, F.R. (1989), Paradoxical effects of tumour necrosis factor in experimental ovarian cancer. Int. J. Cancer, $44,918-925$.

Malik, S.T., Naylor, M.S., East, N., Oliff, A.\& Balkwill, F.R. (1990), Cells secreting tumour necrosis factor show enhanced metastasis in nude mice. Eur. J. Cancer, 26, 1031-1034.

Männel, D.N., Kist, A., Ho, A.D., Rath, U., Reichardt, P., Wiedenmann, B., Schlick, E. \& Kirchncr, H. (1989), Tumour necrosis factor production and natural killer cell activity in peripheral blood during treatment with recombinant tumour necrosis factor. Brit. J. Cancer, 60, 585-588.

Männel, D.N., Jänicke, R., Westenfelder, U., Echtcnacher, B., Kist, A. \& Falk, W. (1990), Tumor-induced tumor necrosis factor production in macrophages. $L y m$ phokine Res., 9, 485-489.

McIntosh, J.K., Mule, J.J., Krosnick, J.A. \& Rosenberg, S.A. (1989), Combination cytokine immunothcrapy with tumor necrosis factor alpha, interleukin 2, and alpha-interferon and its synergistic antitumor effects in mice. Cancer Res., 49, 1408-1414.

Miyata, K., Kato, M., Shikama, H., Nishimura, K., Sakae, N., Kawagoe, K., Nishikawa, T., Kuroda, K., Yamaguchi, K., Aoyama, Y., Mitsuishi, Y. \& Yamada, N. (1992), A YIGSR-containing novel mutein without the detrimental effect of human TNF-a of enhancing experimental pulmonary metastasis. Clin. Exp. Metastasis, 10, 267-272.

Mogi, Y., Kogawa, K., Takayama, T., Yoshizaki, N., Bannai, K., Muramatsu, H., Koike, K., Kohgo, Y., Watanabe, N. \& Niitsu, Y. (1991), Platelet aggregation induced by adenosine diphosphate released from 
cloned murine fibrosarcoma cells is positively correlated with the experimental metastatic potential of the cells. Jap. J. Cancer Res., 82, 192-198.

Naylor, M.S., Malik, S.T., Stamp, G.W., Jobling, T. \& Balkwill, F.R. (1990), In situ detection of tumour necrosis factor in human ovarian cancer specimens. Eur. J. Cancer, 26, 1027-1030.

Nierodzik, M.L., Plotkin, A., Kajumo, F. \& Karpatkin, S. (1991), Thrombin stimulates tumor-platelet adhesion in vitro and metastasis in vivo. J. Clin. Invest., $87,229-236$

Okoshi, H., Hakomori, S., Nisar, M., Zhou, Q.H., Kimura, S., Tashiro, K. \& Igarashi, Y. (1991), Cell membrane signaling as target in cancer therapy. II. Inhibitory effect of $\mathrm{N}, \mathrm{N}, \mathrm{N}$-trimethylsphingosine on metastatic potential of murine B16 melanoma cell line through blocking of tumor cell-dependent platelet aggregation. Cancer Res., 51, 6019-6024.

Old, L.J. (1985), Tumor necrosis factor (TNF). Science, $230,630-633$.

Opdenakker, G. \& Van Damme, J. (1992), Cytokines and proteases in invasive processes: molecular similarities between inflammation and cancer. Cytokine, 4, $251-258$.

Ordinas, A., Diaz Ricart, M., Almirall, L. \& Bastida, E. (1990), The role of platelets in cancer metastasis. Blood Coagul. Fibrinolysis, 1, 707-711.

Orosz, P., Echtenacher, B., Falk, W., Rüschoff, J., Weber, D. \& Männel, D.N. (1993), Enhancement of experimental metastasis by tumor necrosis factor. J. Exp. Med. (in press).

Palladino, M.A., Shalaby, M.R., Kramer, S.M., Ferraiolo, B.L., Baughman, R.P., Deleo, A.A., Crase, G., Marifino, G., Aggarwal, B.B., Figari, I.S., Liggitt, D. \& Patton, J.S. (1987), Characterization of the antitumor activities of human tumor necrosis factor alpha and the comparison with other cytokines: induction of tumor-specific immunity. J. Immunol., $138,4023$.

Pfizenmaier, K., Scheurich, P., Schluter, C. \& Kronke, M. (1987), Tumor necrosis factor enhances HLA-A,B,C and HLA-DR gene expression in human tumor cells. J. Immunol., 138, 975-980.

Rakhmilevich, A.L. \& North, R.J. (1991), Rapid acquisition of an enhanced capacity to produce tumor necrosis factor, alpha/beta interferon, and interleukin-6 after implantation of tumor cells. Cytokine, 3, 398 .

Reibnegger, G., Hetzel, H., Fuchs, D., Fuith, L.C., Hausen, A., Werner, E.R. \& Wachter, H. (1987),
Clinical significance of neopterin for prognosis and follow-up in ovarian cancer. Cancer Res., 47, 4977.

Reibnegger, G., Krainer, M., Herold, M., Ludwig, H., Wachter, H. \& Huber, H. (1991), Predictive value of interleukin-6 and neopterin in patients with multiple mycloma. Cancer Res., 51, 6250.

Renesto, P. \& Chignard, M. (1991), Tumor necrosis factoralpha enhances platelet activation via cathepsin G released from neutrophils. J. Immunol., 146, 2305-2309.

Rice, G.E., Gimbrone, M.A.J. \& Bevilacqua, M.P. (1988), Tumor cell-endothelial interactions. Increased adhesion of human melanoma cells to activated vascular endothelium. Am. J. Pathol., 133, 204-210.

Sugarman, B.J., Aggarwal, B.B., Hass, P.E., Figari, I.S., Palladino, M.A. \& Shepard, H.M. (1985), Recombinant human tumor necrosis factor-a: effects on proliferation on normal and transformed cells in vitro. Science, 230, 943-945.

Sugimoto, Y., Watanabe, M., Ohara, T., Sato, S., Isoe, T. \& Tsuruo, T. (1991), Suppression of experimental lung colonization of a metastatic variant of murine colon adenocarcinoma 26 by a monoclonal antibody 8F1l inhibiting tumor cell-induced platelet aggregation. Cancer Res., 51, 921-925.

Sylvester, D.M., Liu. S.Y. \& Meadows, G.G. (1990), Augmentation of antimetastatic activity of interferon and tumor necrosis factor by heparin. Immunopharmacol. Immunotoxicol., 12, 161-180.

Tanaka, M. (1989), Induction of tissue factor-like activity of human monoblastic leukemia cell line by tumor necrosis factor-alpha. Thromb. Res., 56, 201-211.

Tanaka, Y., Adams, D.H., Hubscher, S., Hirano, H., Siebenlist, H. \& Shaw, S. (1993), T-cell adhesion induced by proteoglycan-immobilized MIP-1 beta. Nature (Lond.), 361, 79-82.

Tomazic, V.J., Farha, M., Loftus, A. \& Elias, E.G. (1988), Anti-tumor activity of recombinant tumor necrosis factor on mouse fibrosarcoma in vivo and in vitro. $J$. Immunol., 140, 4056-4061.

Tzanakakis, G.N., Agarwal, K.C., Veronikis, D.K. \& Vezeridis, M.P. (1991), Effects of antiplatelet agents alone or in combinations on platelet aggregation and on liver metastases from a human pancreatic adenocarcinoma in the nude mouse. J. Surg. Oncol., $48,45-50$.

Wiggins, R.C., Njoku, N. \& Sedor, J.R. (1990), Tissue factor production by cultured rat mesangial cells. Stimulation by TNF alpha and lipopolysaccharide. Kidney Int., 37, 1281-1285. 